\title{
Covid-19 Salgını Sürecinde 10-14 Yaş Aralığındaki Çocukların Fiziksel Uygunluk Düzeylerinin Belirlenmesi*
}

\author{
Yunus Emre GÜLHAN ${ }^{1 \dagger}$ (D), Selçuk AKPINAR ${ }^{2}$ \\ ${ }^{1}$ Nevşehir Hacı Bektaş Veli Üniversitesi, Sosyal Bilimler Enstitüsü, Nevşehir. \\ ${ }^{2}$ Nevşehir Hacı Bektaş Veli Üniversitesi, Eğitim Fakültesi, Nevşehir.
}

Orijinal Makale

Gönderi Tarihi: 17.07.2021
Kabul Tarihi: 05.12.2021
DOI:10.25307/jssr.971641

Online Yayın Tarihi: 31.12.2021

\section{$\ddot{O} \mathbf{z}$}

Hareketsiz yaşam tarzı, tüm yaş gruplarındaki bireylerin sahip oldukları fiziksel uygunluk düzeylerinde gerilemeye neden olabilmektedir. Covid 19 salgını sürecinin neden olduğu hareketsiz yaşamın, bireylerin fiziksel uygunluk düzeylerinde gerilemeye yol açtığı düşünülmektedir. Bu araştırmanın amacı, covid-19 salgını sürecinde 10-14 yaş aralığındaki çocukların fiziksel uygunluk düzeylerinin belirlenmesidir. Araştırmaya 2020-2021 eğitim yılında Yozgat ilinin Çayıralan ilçesinde, Millî Eğitim Bakanlığı bünyesindeki ortaokul ve lise düzeylerinde öğrenimlerine devam eden toplam 30 öğrenci (15 k1z, 15 erkek) gönüllü olarak katılım göstermiştir. Araştırma dahilinde katılımcıların performansla ilişkili fiziksel uygunluklarının belirlenmesi amacıyla 3 adım sıçrama, sağlık topu firlatma, yıldız çeviklik koşusu, $50 \mathrm{~m}$ sürat koşusu ve 9 dk. dayanıklılık koşusu testlerinin uygulamaları gerçekleştirilmiştir. Testlerin uygulamalarından elde edilen verilerin analizinde tanımlayıcı istatistik verilerinden, bağımlı değişkenlere ait ortalamaların karşılaştırılmasında Tek Örneklem t Testinden, örneklemin yaş gruplarına göre karşılaştırılması amacıyla Tek Yönlü Varyans Analizinden ve gruplar arası farklılığın tespit edilmesi amacıyla Scheffe Çoklu Karşılaştırma Testinden yararlanılmıştır. Sonuç olarak; araştırmamızın katılımcılarına ait fiziksel uygunluk performanslarını ifade eden ortalama değerlerin (14 yaş grubu erkeklerin $50 \mathrm{~m}$. sürat testinden elde ettikleri ortalama değer hariç), salgın süreci öncesinde gerçekleştirilmiş ve fiziksel uygunluk açısından bir standart olarak kabul edilen ortalama yüzdelik değerlere göre (Golle vd., 2015) \%30'luk dilimin altında kaldığı tespit edilmiștir. Katılımcılara ait yaş gruplarının kendi içerisinde karşılaştırılması sonucunda ise, 12 yaş grubu ile 14 yaş grubu katılımcıların sağlık topu firlatma testi ortalamaları arasında anlamlı düzeyde farklılığın oluştuğu gözlemlenmiştir $(\mathrm{p}<0,05)$. Genel olarak, Covid 19 salgını sonrasında 10-14 yaş grubundaki çocukların fiziksel uygunluk parametrelerinin Avrupa genelinde norm olarak kabul edilen değerlerin çok altında olduğu tespit edilmiştir.

Anahtar kelimeler: Hareketsiz yaşam, Motor gelişim, Fiziksel aktivite, Dayanıklılık, Çeviklik.

\section{Determining the Physical Fitness Levels of Children Aged 10-14 During the Covid-19 Pandemic}

\begin{abstract}
Inactive lifestyle can cause a decline in the physical fitness levels of individuals in all age groups. It is thought that the inactive life caused by the Covid 19 epidemic process leads to a decline in the physical fitness levels of individuals. The aim of this research is to determine the physical fitness levels of children between the ages of 10-14 during the covid-19 epidemic. A total of 30 students (15 girls, 15 boys) who study at secondary and high schools affiliated to the Ministry of National Education in the Çayıralan district of Yozgat province in the 2020-2021 academic year voluntarily participated to this study. Within the scope of the research, in order to determine the performance-related physical fitness of the participants, triple hop, medicine ball throwing, star agility run, $50 \mathrm{~m}$ sprint and 9 min. endurance running tests were carried out. Descriptive statistics data were used in the analysis of the data obtained from the applications of the tests. One Sample t-Test was used to compare the means of dependent variables, One-Way ANOVA was conducted to compare the sample according to age groups, Scheffe Multiple Comparison Test was used to determine the difference between groups. As a result; the mean values expressing the physical fitness performances of the participants of our study (excluding the mean value obtained from the $50 \mathrm{~m}$ sprint test for 14-yearold men) were compared to the average percentage values that were performed before the epidemic and accepted as a standard in terms of physical fitness (Golle et al., 2015) were found to be below the $30 \%$ tranche. As a result of the comparison of the age groups of the participants, it was observed that there was a significant difference in the medicine ball throwing test averages in the 12-year-old and 14-year-old participants $(\mathrm{p}<0.05)$. In general, after the Covid 19 epidemic, it was determined that the physical fitness parameters of children in the 10-14 age group were far below the values accepted as the norm across Europe. Keywords: Sedentary life, Motor development, Physical activity, Endurance, Agility.
\end{abstract}

"Bu çalışma, Yunus Emre GÜLHAN'ın Nevşehir Hacı Bektaş Veli Üniversitesi, Sosyal Bilimler Enstitüsü'nce kabul edilen "Covid-19 Salgını Sürecinde 10-14 Yaş Aralığındaki Çocukların Fiziksel Uygunluk Düzeylerinin Belirlenmesi" başlıklı yüksek lisans tezinden üretilmiştir.

*Sorumlu yazar: Yunus Emre GÜLHAN, E-posta: yunusemregulhan@gmail.com 


\section{GíRIş}

Geçmişten günümüze kadar çeşitli sebeplerle insanların fiziksel aktivite düzeylerinde azalma ve buna bağlı olarak daha durağan bir yaşam tarzına geçiş yaşanmış, dolayısıyla insanların günlük aktivitelerini gerçekleştirebilmeleri için ihtiyaç duydukları potansiyeli sağlamaları güçleşmiştir. Zamanla barınma olanaklarının konforlu hale gelmesi, çeşitli ulaşım araçlarıyla uzun mesafelere ulaşımın kolaylaşması, ekonomik yeterliliğin artması vb. sebeplerle insanların daha rahat yaşam standartlarına ulaşmaları enerji sarf etme ihtiyacını azaltarak insanları hareketsiz kılan diğer faktörlerden bazılarıdır. Bu durağanlık insanları özellikle bedensel, zihinsel, sosyal, ruhsal ve psikolojik açıdan olumsuz etkilemiştir (Akpınar, 2020). Bahsedilen hareketsiz yaşam kaynaklarına ek olarak, dünya genelinde belli zaman dilimlerinde yaşanan sağlık problemlerinin başında gelen salgınlar da insanların yaşam biçimlerinde köklü değişiklikler yapmalarına sebep olmuştur. Bu noktada sosyal, kültürel ve ekonomik şartların ötesinde toplumların yaşam tarzlarını da farklılaştıran Covid-19 pandemisi süreci bireylerin hareketsiz bir yaşam sürmesini zorunluluk haline dönüştürmüştür (Tetik, 2021).

2019 yılının son günleri yaşanırken Çin'in Vuhan Eyaleti'nde bölgesel çapta bir salgın (epidemi) olarak ortaya çıkan Covid-19 13 Ocak 2020'de bir grup hasta üzerinde yapılan incelemeler sonucu tanımlanmış, ilerleyen süreçte insanlar arasında bulaş yoluyla yaygınlaşarak Vuhan eyaleti başta olmak üzere Çin Halk Cumhuriyeti'nin diğer eyaletlerine ve ardından tüm dünya geneline yayılarak pandemi boyutunda etkisini göstermiştir (T.C. Sağlık Bakanlığı, 2020a). Epidemi (salgın), bir hastalığın bir yerde belirli bir zaman diliminde beklenenden fazla görülmesi ya da belirli ortak özellikleri nedeniyle kümeleşme göstermesidir (Şardan, 2008). Bir hastalığın veya enfeksiyon faktörünün çok geniş bir alanda (ülkeler, kıtalar vb.) sirayet etmesi ise pandemi olarak nitelendirilir (T.C. Sağlık Bakanlığı, 2020b).

Covid-19 sürecinde, pandeminin yayılma hızının ve bulaşıcılık riskinin azaltılmasının en önemli tedbiri olarak izolasyon uygulamasının gündeme gelmesiyle birlikte insanlar, kendi yaşam alanlarında bu uygulamayı hayata geçirerek dış dünyadan izole olmayı tercih etmişlerdir. Karantina sebebiyle günlük rutinleri farklılaşan, kısıtlanan ya da tamamen sona eren bireyler, alışı oldukları hareketlilikten uzaklaşarak hareket etme ve enerji sarf etme ihtiyacı daha az olan faaliyetlerle meşgul olmaya başlamışlardır.

Bu noktada izolasyon uygulamasının salgına karşı tedbir açısından olumlu sonuçlar verdiği (Erkal, Ses, Saliha ve Çalışkan, 2020; Peçanha, Goessler, Roschel ve Gualano, 2020), ancak diğer yandan insanları fiziksel olarak aktif olma konusunda olumsuz etkilediğini de göz önünde bulundurmak gerekir (Crisafulli ve Pagliaro, 2020). Bunun yanısıra özellikle büyüme ve gelişim süreçleri devam eden ve hareket etme ihtiyaçları diğer yaş gruplarına göre daha fazla olan bireylerin, bu süreçten daha fazla etkilendiğini ve etkilenmeye devam ettiklerini söylemek mümkündür (Özer ve Özer, 1998).

Alanyazın incelendiğinde, fiziksel aktivite potansiyeli ile fiziksel uygunluk düzeyi arasında doğrusal bir ilişkinin olduğunu söylemek mümkündür (Council of Europa, 2011). Bu doğrusal ilişkiden hareketle, Covid-19 salgını sürecinde fiziksel aktivite potansiyeli azalan bireylerin, bu duruma paralel olarak fiziksel uygunluk düzeylerinde de düşüş gerçekleşmesi beklenmektedir. Buna karşılık Covid-19 pandemisi sürecinde gerçekleştirilecek düzenli fiziksel aktivite ve egzersizlerin, sürecin bir takım olumsuz etkilerinin hafifletilebilmesi; özellikle de pandeminin 
bağışıklık sistemi ve morbidite oranı (hastalığa tutulanların sayısının sağlıklı kalmış nüfusa oranı) üzerindeki olumsuz etkilerini azaltma noktasında faydalı olacağı yapılan çalışmalarla ortaya koyulmuştur (Burtscher, Burtscher ve Millet, 2020; Burtscher ve Burtscher, 2020; Mikkelsen vd., 2017; Nieman ve Wentz, 2019).

Hastalıkları önlemek, bağışıklığı güçlendirmek ve sağlığın korunması amacıyla bireylerin sahip olduğu veya sonradan kazandığı sağlıkla ilgili fiziksel uygunluk parametrelerinin düzeylerini istenen seviyede tutabilmeleri, kronik sağl1k sorunlarından korunma ve yeterli düzeyde günlük yaşam performansının sergilenebilmesi açısından zorunluluk haline geldiğini söylemek mümkündür. $\mathrm{Bu}$ parametreler, çocukların gelecek yaşantıları açısından büyük bir öneme sahiptir (Darilgen, 2006; Koşar, Kin ve Aşçı, 1998; Memiş, 2007; Polat, 2009; Yıkılmaz, 2014).

Fiziksel uygunluk, çocukluk ve ergenlikte sağlık durumunun bir göstergesi olarak görülmelidir. Fiziksel uygunluk gelişimi, zamanla artan yoğunluktaki ve süredeki fiziksel aktiviteye katılım yoluyla yaşanan süreçte ve gelecekte oluşturulacak toplum sağlığı teşvik planlamalarında en önemli hedeflerden birisi olmalıdır. Fiziksel uygunluk düzeyi ile sağlık sorunları arasındaki ilişki göz önünde bulundurulduğunda, fiziksel aktivite etkinlikleri yalnızca kalp-dolaşım sisteminin verimini artırmak için değil; aynı zamanda kassal uygunluğa ek olarak sürat ve çeviklik parametrelerini de geliştirici nitelik taşımalıdır (Ortega, Ruiz, Castillo ve Sjöström, 2008).

Fiziksel uygunluk hem sağlıkla hem de performansla ilişkili parametreleri ihtiva eder. Antropometrik değerler, vücut kompozisyonu, kalp-dolaşım sistemi dayanıklılı̆̆ı, güç, kas kuvveti ve dayanıklılığı, sürat, esneklik, denge ve koordinasyon gibi parametrelerin oluşturduğu bütün fiziksel uygunluğun kapsamını oluşturur (Balc1 vd., 2008; Sönmez, 2006).

Centers for Diase Control and Prevention (CDC) ve Özer’ e (2006) göre sağl1kla ilgili fiziksel uygunluk, kardiyovasküler dayanıklılık, kas kuvveti ve dayanıklılığı, esneklik ve vücut kompozisyonu gibi vücudun işlevsel yetisini artıran parametrelerden oluşur. Bu parametrelerin düşük düzeylere sahip olması; kalp-damar hastalıkları, yüksek tansiyon, beyin damarlarında tıkanıklık, obezite, kemik erimesi, diyabet gibi farklı kronik sağlık sorunlarının yaşanma olasılığını artırmaktadır. Bu parametrelerin düzeylerinde gerçekleşecek olası düşüşler, kişiler için “fiziksel uygunluk düzeyi düşüktür' ifadesi ile tanımlanır (Darilgen, 2006; Kayıhan, 2007; Şahiner, 2009; Yan, 2007).

Beceri ile ilgili fiziksel uygunluk, farklı spor branşlarındaki performans ile ilişkili parametreleri kapsar. Sağlıkla ilgili fiziksel uygunluk parametrelerine ek olarak çeviklik, hız, güç ve reaksiyon zaman1, denge ve koordinasyon gibi parametrelerden meydana gelmektedir. Beceri ile ilgili fiziksel uygunluk düzeyinin tespitinde bireyin yaptığı veya yapmak istediği spor branşına yönelik analizler gerçekleştirilir (Baltacı ve Düzgün, 2008).

Günümüzde bireylerin fiziksel uygunluk düzeyinin belirlenmesi önemli bir ihtiyaç haline gelmiştir. Bu ihtiyacın karşılanması amacıyla, fiziksel uygunluk düzeyinin geçerli ve güvenilir yollarla saptanabilmesi ve elde edilecek verilerin hedeflenen amaca yönelik kullanılabilmesini sağlayan birçok test geliştirilmiştir. Bu testler, bireylerin sahip oldukları bedensel yeterliliğe uygun alanlarda seçim yapabilmelerinin yanı sıra, büyük toplulukların sağlıkla ilgili fiziksel kapasitelerinin belirlenmesinde büyük katkı sağlamaktadır. Zamanla değişen ihtiyaçlara göre 
fiziksel uygunluğun belirlenmesi, sağlik ve performans olmak üzere iki temel unsura odaklanmıştır. Sağlıkla ilişkili fiziksel uygunluk düzeyinin belirlenmesi özellikle sağlıklı ve kaliteli bir yaşamın yanı sıra ülkelerin ve toplulukların sağlık planlamalarına yön vermeyi hedeflerken, performansla ilişkili fiziksel uygunluğun belirlenmesi çeşitli alanlara ya da meslek gruplarına uygun katılımcı profilinin belirlenmesini hedeflemiştir (Kayıhan ve Ersöz, 2010).

Yukarıda bahsedildiği üzere Covid-19 pandemisi sürecinin hareketsiz bir yaşama neden olduğu ve bunun sonucunda bireylerin fiziksel uygunluk düzeylerinde gerileme olabileceği düşünülmektedir. Alan yazın incelendiğinde, Covid-19 pandemisi sürecinin fiziksel uygunluk düzeyleri üzerindeki etkilerini konu alan çalışmaların sayısının az olduğu gözlemlenmektedir. Uluslararası alanda çocukların sahip oldukları fiziksel uygunluk düzeyleri ile ilgili standartların ortaya konulduğu çalışmalar mevcuttur (Golle, Granacher, Muehlbauer ve Wick, 2015). Bu çalışmalar Covid-19 sürecinden önce yapılmış olup, çocukların hareket sınırlılıklarının olmadığı dönemi kapsamaktadır. Bu çalışmanın amacı; 10-14 yaş aralığındaki çocukların Covid 19 salgını sürecinde performansa dayalı fiziksel uygunluklarının belirlenmesi ve bu değerlerin Avrupa genelinde norm kabul edilen değerler ile karşılaştırılması olarak belirlenmiştir.

\section{YÖNTEM}

\section{Araştırma Modeli}

$\mathrm{Bu}$ araştıma, tarama modelli araştırmalardan kesitsel tarama deseni ile gerçekleştirilmiştir. Tarama modelli araştırmalar, geçmişte gerçekleşen ya da günümüzde halen devam eden bir durumu, olduğu gibi tasvir etmeyi amaçlayan bir araştırma modelidir. Tarama modelli araştırmaların alt desenlerinden birisi olan kesitsel tarama deseninde amaç, taranan durumun zaman içerisindeki farklılaşımından ziyade herhangi bir zaman dilimindeki durumunu tanımlamaktır (Karasar, 2012).

\section{Araştırma Grubu}

Bu araştırmanın evrenini, 2020-2021 eğitim yılında Yozgat ilinin Çayıralan ilçesinde Millî Eğitim Bakanlığı'na bünyesinde hizmet veren ortaokul (25 öğrenci) ve lise (5 öğrenci) düzeylerindeki eğitim kurumlarında öğrenimlerine devam eden öğrenciler oluşturmaktadır. Bu evren içerisinden rastgele yöntemle seçilen 10-14 yaş aralığındaki 30 öğrenci (15 kız, 15 erkek)

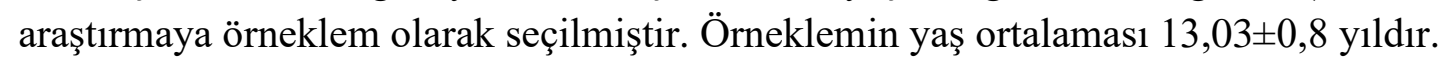

Tablo 1. Araştırma örnekleminin eğitim düzeyi, yaş ve cinsiyet değişkenlerine göre dağılımları

\begin{tabular}{cccccccc}
\hline & & \multicolumn{2}{c}{ 12 Yaş } & \multicolumn{2}{c}{ 13 Yaş } & \multicolumn{2}{c}{14 Yaş } \\
\cline { 3 - 8 } & & Kuz & Erkek & Kuz & Erkek & Kuz & Erkek \\
\cline { 3 - 8 } & 6. & 5 & 3 & 0 & 0 & 0 & 0 \\
Ĕgitim Düzeyi & 7. & 1 & 0 & 4 & 5 & 0 & 0 \\
(Sınıf) & 8. & 0 & 0 & 2 & 0 & 3 & 2 \\
& 9. & 0 & 0 & 0 & 0 & 0 & 5 \\
\hline
\end{tabular}




\section{Veri Toplama Araçları}

Katılımcılara ait performansa dayalı fiziksel uygunluk düzeylerinin belirlenmesi amacıyla Motor Uygunluk Test Bataryası (Bös vd., 2009; Golle vd., 2015; Stark, 2000) dahilindeki 50 m sürat koşusu, yıldız çeviklik koşusu, $9 \mathrm{dk}$. dayanıklılık koşusu, sağlık topu firlatma ve 3 adım sıçrama testlerinin uygulamaları gerçekleştirilmiştir. Bu testlere ek olarak katılımcılara ait boy uzunluğu ve vücut ağırlığı ölçümleri alınarak katılımcıların bu iki ölçüme bağlı beden-kütle indeksi skorları hesaplanmıştır.

\section{Verilerin Toplanması}

Verilerin toplanması sürecinde motor uygunluk test bataryaları (Bös vd., 2009; Golle vd., 2015; Stark, 2000) kullanılmıştır.

\section{Metre Sürat Testi}

Bu test için ölçümü yapılacak katılımcı, belirlenen başlangıç noktasında atletizmde yüksek çıkış pozisyonunda hazır halde beklemiştir. Başlangıç komutu ile sürat testine başlayan denekten, 2 kez ölçüm alınmıştır. Ölçümler arasından daha iyi olan sonuç, deneğin sürat skoru olarak hanesine kaydedilmiştir (Golle vd., 2015).

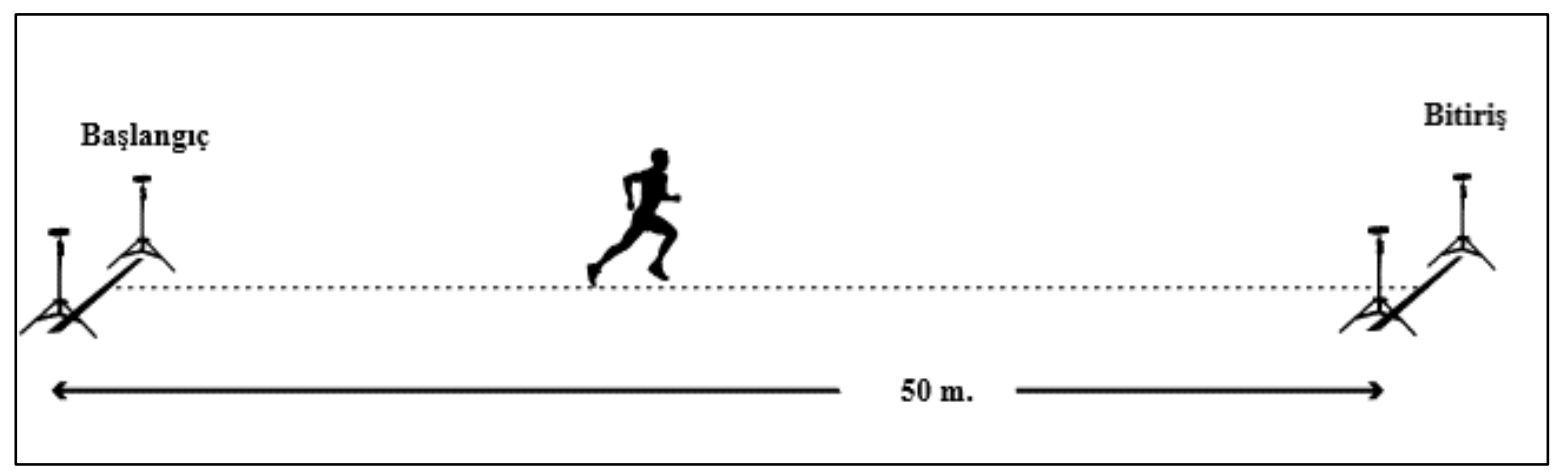

Şekil 1. 50 m. Sürat Testi

\section{Sağlık Topu Fırlatma Testi}

Üst ekstremite kas gücünün belirlenmesi amacıyla gerçekleştirilen bu test için, 1 kg ağırlığında sağlık topu kullanılmıştır. Fırlatmaya başlangıç noktası, 25 santimetre çapında bir bant yardımıyla belirlenmiştir. Ölçümü yapılacak denekten, firlatma işlemini vücudun her iki tarafı ile ayrı ayrı yapması istenmiştir. Sağ ya da sol elle firlatma işlemini gerçekleştirecek denek, sağ ya da sol dizini daha düşük pozisyonda ve bacağı ile uyluğu arasında 90 derecelik açı olacak şekilde yere paralel olarak yerleştirmiştir. Bu pozisyondayken sağ ya da sol eliyle kavradığı topu boynuna yanaştırmıştır. Boşta kalan kolu ise, gergin ve firlatma yönünü gösterecek pozisyondadır. Denekten belirtilen fırlatma pozisyonunda bir dakikalık dinlenme ile 2 atış gerçekleştirmesi beklenmiştir. Gerçekleştirilen firlatma işlemlerinden daha iyi olana ait skor, deneğin firlatma skoru olarak hanesine kaydedilmiştir (Golle vd., 2015). 


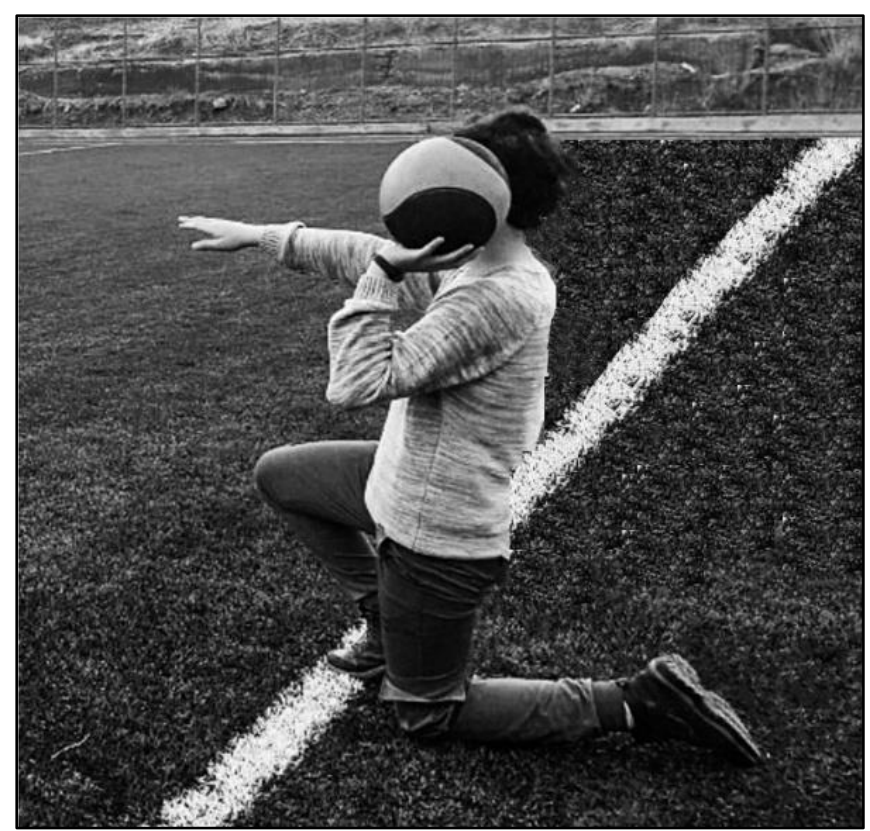

Şekil 2. Sağlik topu firlatma testi

\section{Adım Sıçrama Testi}

Alt ekstremite kas gücünün belirlenmesi amaciyla gerçekleştirilen bu test için, öncelikle başlangıç noktası belirlenmiştir. Başlangıç noktasında sıçrama ayağı üzerinde hazır halde bekleyen deneklerden, hazır oldukları anda başlangıç çizgisinin gerisinden aynı ayakla ileriye doğru 3 kez sıçrayıp en sonuncu sıçramanın ardından iki ayak üzerine inmeleri istenmiştir. Bu işlem vücudun her iki tarafi için $2 \mathrm{kez}$ tekrar edilmiştir. Ölçümler arasından en iyi skor, deneklerin sıçrama skoru olarak hanelerine kaydedilmiştir (Golle vd., 2015).

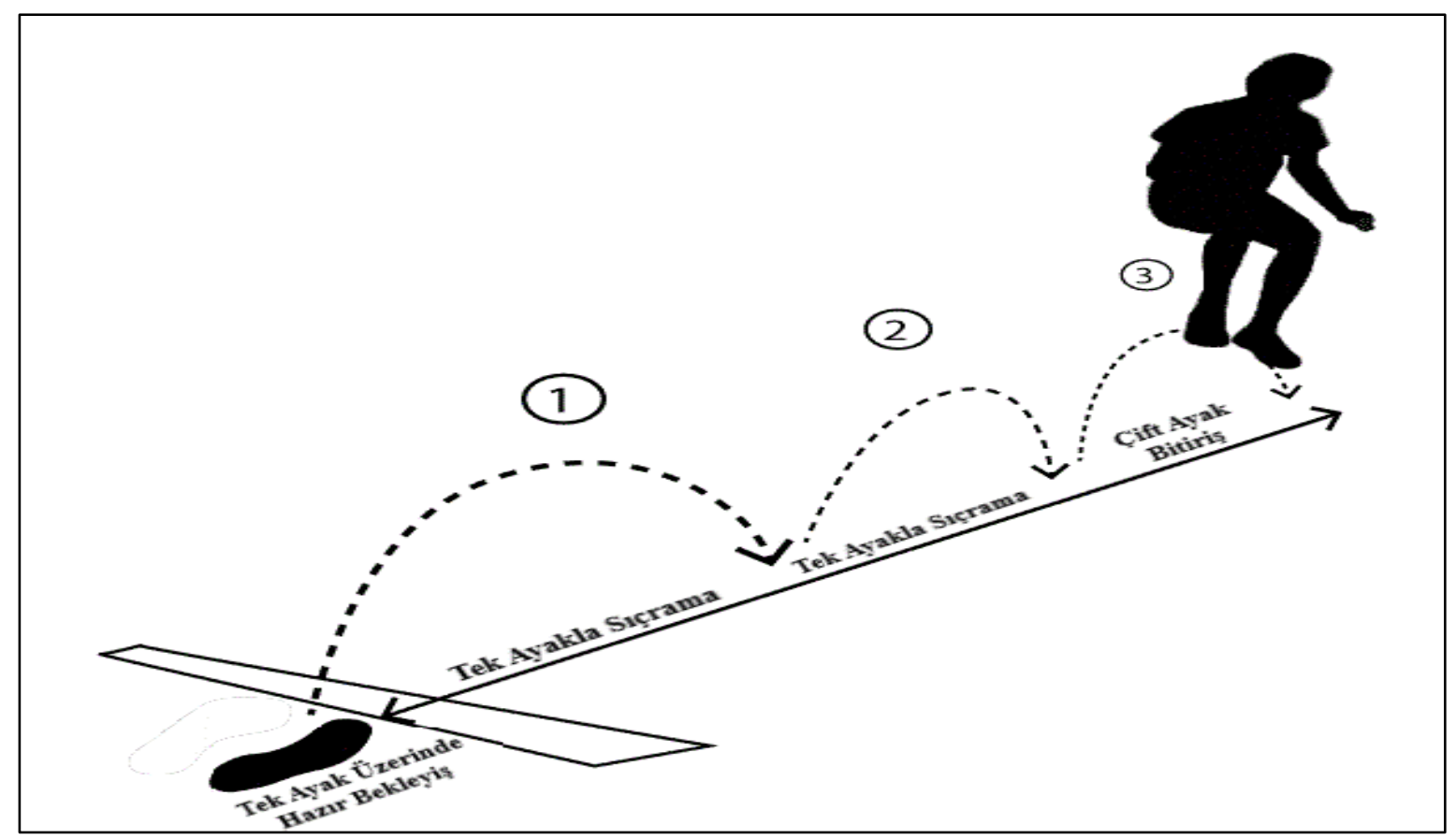

Şekil 3. Üç adım sıçrama testi 


\section{Yıldız Çeviklik Koşusu Testi}

9 x 9 metrekarelik bir alanda gerçekleştirilen test için öncelikle testin yapılacağı alanın köşe noktaları ve alanın merkezi 30 santimetre yüksekliğinde huniler yardımıyla belirlenmiştir. Test alanının merkezini belirten huni, test için başlangıç noktasıdır. Ölçümü yapılacak denek, alanın merkezindeki başlangıç hunisinin gerisinde hazır halde beklemiştir. Başlangıç komutu ile teste başlayacak denek, öncelikle başlangıç yönüne göre test alanının sağ köşesindeki huninin etrafını dolaşarak tekrar başlangıç noktasına gelmiştir. Alanın, kalan diğer 3 köşesinde bulunan huni ile alanın merkez noktasındaki huni arasında da bu işlemi gerçekleştirecek denek testi tamamlamış sayılmıştır. Denekten, bu hareket setini 5 dakika dinlenme aralığıyla $2 \mathrm{kez}$ gerçekleştirmesi istenmiştir. 2 denemeye ait en iyi skor, deneğin çeviklik skoru olarak hanesine kaydedilmiştir (Golle vd., 2015).

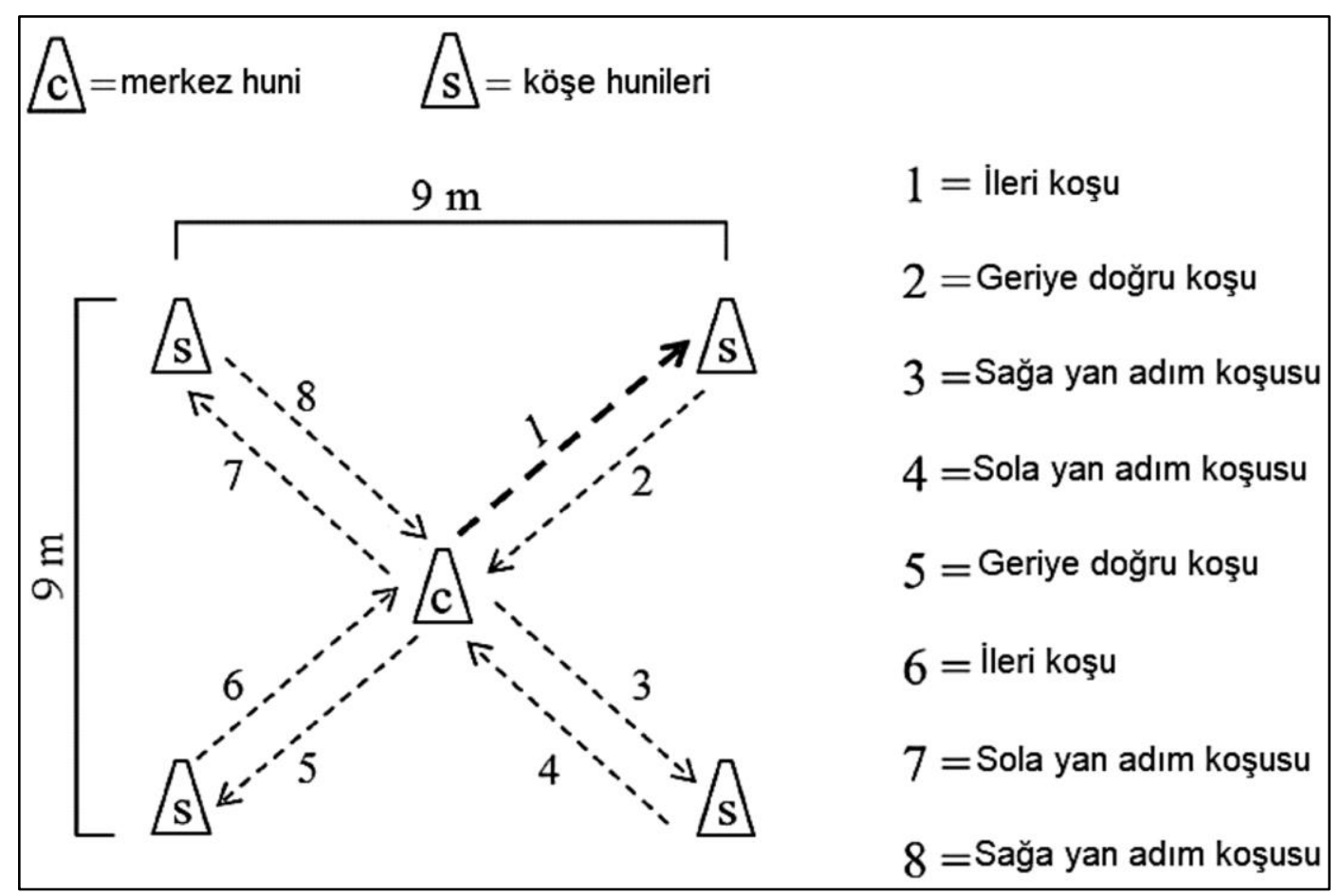

Şekil 4. Yıldız çeviklik koşusu testi

\section{Dakika Dayanıklıık Koşusu Testi}

$\mathrm{Bu}$ test, deneklerin aerobik kapasitesinin değerlendirilmesi amacıyla açık havada gerçekleştirilmiştir. Bu test için deneklerden, çevre uzunluğu 400 metre olan atletizm pistinde 9 dakika boyunca en uzak mesafeyi koşmaları beklenmiştir. Denekler, başlangıç noktasında hazır halde bekleyip başlangıç komutu ile teste başlamışlardır. Tek denemenin gerçekleştirileceği testte, deneklere ait koşu mesafeleri dayanıklılık skoru olarak hanelerine kaydedilmiştir (Golle vd., 2015).

\section{Araştırma Yayın Etiği}

Araştırma, Nevşehir Hacı Bektaş Veli Üniversitesi Girişimsel Olmayan Klinik Araştırmalar Etik Kurul Başkanlığı tarafından 23/10/2020 - 2020.19.277 karar numarası ile onaylanmıştır. 
Gülhan, Y.E. ve Akpınar, S. (2021). Covid-19 salgını sürecinde 10-14 yaş aralığındaki çocukların fiziksel uygunluk düzeylerinin belirlenmesi. Spor Bilimleri Araştırmaları Dergisi, 6(2), 365-383.

\section{Verilerin Analizi}

Katılımcılara uygulanan Motor Uygunluk Test Bataryası testlerinden elde edilen bağımlı değişkenlere ait ortalamalar ile Physical Fitness Percentiles of German Children Aged 9-12 Years: Findings from a Longitudinal Study (9-12 Yaş Arasındaki Alman Çocukların Fiziksel Uygunluk Yüzdelikleri: Boylamsal Bir Çalışmadan Elde Edilen Bulgular) (Golle vd., 2015) araştırmasına ait ortalamaların karşılaştırılması amacıyla Tek Örneklem t Testi, örneklemin yaş gruplarına göre karşılaştırılması amacıyla Tek Yönlü Varyans Analizi ve gruplararası farklılığın tespit edilmesi amacıyla Scheffe Çoklu Karşılaştırma Testi kullanılmıştır. Bunlara ek olarak ortalama (Ort.), standart sapma (S) gibi tanımlayıcı istatistik verilerinden de yararlanılmıştır. Araştırmaya ait veri analizi işlemlerinin tamamı "IBM SPSS Statistics 22" istatistiksel analiz paket programı aracılığıyla gerçekleştirilmiştir. Araştırma verilerinin analizinde 0.05 anlamlılık düzeyi esas alınmıştır.

Tablo 2. Golle ve diğerlerinin (2015) araştırmasına ait istatistiksel veriler: 9-12 yaş arası erkek $(\mathrm{n}=152)$ ve kızlarda $(\mathrm{n}=88)$ antropometri ve fiziksel uygunluk gelişimi

\begin{tabular}{|c|c|c|c|c|c|c|c|c|c|c|c|}
\hline \multirow[t]{2}{*}{ Yaş } & \multicolumn{2}{|c|}{9} & \multicolumn{2}{|c|}{10} & \multicolumn{2}{|c|}{11} & \multicolumn{2}{|c|}{12} & \multicolumn{3}{|c|}{$\begin{array}{c}\text { Ana / Etkileşim Etkisi: } \\
\text { p-değeri }(d)\end{array}$} \\
\hline & Erkek & $\mathbf{K} \mathbf{z z}$ & Erkek & Kız & Erkek & $\mathbf{K i z}$ & Erkek & Kız & Cinsiyet & Yaş & Yaş/Cinsiyet \\
\hline $\begin{array}{c}\text { Vücut } \\
\text { A ğırlığ } 1 \\
(\mathrm{~kg})\end{array}$ & $\begin{array}{l}33,1 \\
(6,1)\end{array}$ & $\begin{array}{l}31,7 \\
(5,4)\end{array}$ & $\begin{array}{l}37,3 \\
(7,3)\end{array}$ & $\begin{array}{l}36,0 \\
(7,0)\end{array}$ & $\begin{array}{l}42,6 \\
(9,1)\end{array}$ & $\begin{array}{l}41,0 \\
(8,8)\end{array}$ & $\begin{array}{c}47,6 \\
(10,0)\end{array}$ & $\begin{array}{c}46,3 \\
(10,1)\end{array}$ & $\begin{array}{c}.183 \\
(0,17)\end{array}$ & $\begin{array}{l}<, 001 \\
(4,21)\end{array}$ & $\begin{array}{c}, 873 \\
(0,04)\end{array}$ \\
\hline $\begin{array}{c}\text { Boy } \\
\text { Uzunluğu } \\
(\mathrm{cm})\end{array}$ & $\begin{array}{l}140,5 \\
(6,2)\end{array}$ & $\begin{array}{r}138,1 \\
(5,8)\end{array}$ & $\begin{array}{c}144,8 \\
(6,7)\end{array}$ & $\begin{array}{r}142,3 \\
(6,2)\end{array}$ & $\begin{array}{l}150,8 \\
(7,1)\end{array}$ & $\begin{array}{l}150,0 \\
(6,9)\end{array}$ & $\begin{array}{r}156,8 \\
(8,0)\end{array}$ & $\begin{array}{l}155,9 \\
(7,2)\end{array}$ & $\begin{array}{l}, 066 \\
(0,24)\end{array}$ & $\begin{array}{l}<, 001 \\
(6,88)\end{array}$ & $\begin{array}{l}<, 001 \\
(0,42)\end{array}$ \\
\hline $\begin{array}{c}\mathrm{BKI} \\
\left(\mathrm{kg} / \mathrm{m}^{2}\right)\end{array}$ & $\begin{array}{l}16,7 \\
(2,5)\end{array}$ & $\begin{array}{l}16,6 \\
(2,3)\end{array}$ & $\begin{array}{l}17.7 \\
(2.7)\end{array}$ & $\begin{array}{l}17.7 \\
(2.7)\end{array}$ & $\begin{array}{l}18.6 \\
(3.1)\end{array}$ & $\begin{array}{l}18.1 \\
(3.0)\end{array}$ & $\begin{array}{l}19.2 \\
(3.1)\end{array}$ & $\begin{array}{l}18.9 \\
(3.3)\end{array}$ & $\begin{array}{c}.514 \\
(0.09)\end{array}$ & $\begin{array}{l}<.001 \\
(1.91)\end{array}$ & $\begin{array}{l}.101 \\
(0.19)\end{array}$ \\
\hline $\begin{array}{c}50 \mathrm{~m} \\
\text { Sürat (sn.) }\end{array}$ & $\begin{array}{l}9.6 \\
(0.8)\end{array}$ & $\begin{array}{l}9.8 \\
(0.9)\end{array}$ & $\begin{array}{c}9.2 \\
(0.9)\end{array}$ & $\begin{array}{c}9.5 \\
(0.9)\end{array}$ & $\begin{array}{c}8.9 \\
(0.8)\end{array}$ & $\begin{array}{l}9.0 \\
(0.8)\end{array}$ & $\begin{array}{c}8.7 \\
(0.8)\end{array}$ & $\begin{array}{c}8.8 \\
(0.8)\end{array}$ & $\begin{array}{c}.314 \\
(0.13)\end{array}$ & $\begin{array}{l}<.001 \\
(0.69)\end{array}$ & $\begin{array}{c}.324 \\
(0.14)\end{array}$ \\
\hline $\begin{array}{c}\text { Sağlık } \\
\text { Topu } \\
\text { Fırlatma } \\
\quad(\mathrm{m})\end{array}$ & $\begin{array}{c}7.91 \\
(1.41)\end{array}$ & $\begin{array}{c}6.40 \\
(1.30)\end{array}$ & $\begin{array}{c}8.93 \\
(1.51)\end{array}$ & $\begin{array}{c}7.56 \\
(1.26)\end{array}$ & $\begin{array}{l}10.70 \\
(1.92)\end{array}$ & $\begin{array}{c}8.84 \\
(1.60)\end{array}$ & $\begin{array}{l}11.57 \\
(2.31)\end{array}$ & $\begin{array}{c}9.79 \\
(1.71)\end{array}$ & $\begin{array}{l}<.001 \\
(0.55)\end{array}$ & $\begin{array}{l}<.001 \\
(0.40)\end{array}$ & $\begin{array}{l}<.001 \\
(0.36)\end{array}$ \\
\hline $\begin{array}{c}3 \text { Adım } \\
\text { Sıçrama } \\
(\mathrm{m}) \\
\text { Yıldız }\end{array}$ & $\begin{array}{c}7.65 \\
(1.24)\end{array}$ & $\begin{array}{c}7.26 \\
(1.15)\end{array}$ & $\begin{array}{c}8.44 \\
(1.19)\end{array}$ & $\begin{array}{c}8.04 \\
(1.21)\end{array}$ & $\begin{array}{c}9.17 \\
(1.26)\end{array}$ & $\begin{array}{c}8.83 \\
(1.16)\end{array}$ & $\begin{array}{c}9.78 \\
(1.43)\end{array}$ & $\begin{array}{c}9.37 \\
(1.31)\end{array}$ & $\begin{array}{c}.096 \\
(0.22)\end{array}$ & $\begin{array}{l}<.001 \\
(0.67)\end{array}$ & $\begin{array}{c}.114 \\
(0.19)\end{array}$ \\
\hline $\begin{array}{l}\text { Çeviklik } \\
\text { Koşusu } \\
\text { (sn.) }\end{array}$ & $\begin{array}{l}23.2 \\
(3.3)\end{array}$ & $\begin{array}{l}23.9 \\
(3.0)\end{array}$ & $\begin{array}{l}21.0 \\
(2.1)\end{array}$ & $\begin{array}{l}22.0 \\
(2.1)\end{array}$ & $\begin{array}{l}19.6 \\
(1.9)\end{array}$ & $\begin{array}{l}20.3 \\
(1.8)\end{array}$ & $\begin{array}{l}19.0 \\
(1.9)\end{array}$ & $\begin{array}{l}19.5 \\
(1.7)\end{array}$ & $\begin{array}{c}.001 \\
(0.44)\end{array}$ & $\begin{array}{l}<.001 \\
(1.34)\end{array}$ & $\begin{array}{c}.004 \\
(0.27)\end{array}$ \\
\hline $\begin{array}{c}9 \mathrm{dk} . \\
\text { Koşu (m) }\end{array}$ & $\begin{array}{l}1471 \\
(203)\end{array}$ & $\begin{array}{l}1319 \\
(204)\end{array}$ & $\begin{array}{l}1569 \\
(269)\end{array}$ & $\begin{array}{l}1417 \\
(225)\end{array}$ & $\begin{array}{l}1606 \\
(248)\end{array}$ & $\begin{array}{l}1467 \\
(201)\end{array}$ & $\begin{array}{l}1598 \\
(258)\end{array}$ & $\begin{array}{l}1469 \\
(218)\end{array}$ & $\begin{array}{c}.014 \\
(0.32)\end{array}$ & $\begin{array}{l}<.001 \\
(0.79)\end{array}$ & $\begin{array}{l}.113 \\
(0.18)\end{array}$ \\
\hline $\begin{array}{c}\text { Notlar: } \\
\bullet \\
\bullet \\
\bullet \\
\bullet\end{array}$ & $\begin{array}{l}\text { a Göre } \\
\text { ine tek } \\
\text { Etki bü } \\
=\text { Bed }\end{array}$ & $\begin{array}{l}\text { siyet } K \\
\text { anan öl } \\
\text { lüğü C } \\
\text { Gütle İn }\end{array}$ & $\begin{array}{l}\text { S), } \\
\text { laştırma } \\
\text { lerle, } \\
\text { n's d, } \\
\text { si. }\end{array}$ & S & (1) & tem & form & 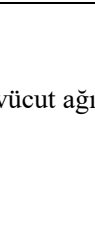 & $\breve{g}_{1}$ ve bo & $k i$ deği & k), yaş \\
\hline
\end{tabular}

Yukarıdaki tabloda araştırmadan elde edilen verilerin karşılaştırmalı olarak yorumlanacağı 912 Yaş Arasındaki Alman Çocukların Fiziksel Uygunluk Yüzdelikleri: Boylamsal Bir Çalışmadan Elde Edilen Bulgular (Golle vd., 2015) araştırmasına ait istatistiksel verilere yer verilmiştir. Araştırmanın örneklemini oluşturan katılımcıların yaş aralığının 12-14 arasında farklılık göstermesi sebebiyle tabloda yer alan verilerden 12 yaş sütununda bulunan bağımlı değişkenlere ait ortalama ve standart sapma skorlarından yararlanılmıştır. 
Gülhan, Y.E. ve Akpınar, S. (2021). Covid-19 salgını sürecinde 10-14 yaş aralığındaki çocukların fiziksel uygunluk düzeylerinin belirlenmesi. Spor Bilimleri Araştırmaları Dergisi, 6(2), 365-383.

Tablo 3. Golle ve diğerlerinin (2015) araştırmasına ait testlerin istatistiksel veriler

\begin{tabular}{|c|c|c|c|c|c|c|c|c|c|}
\hline 12 Yaş & $\% 10$ & $\% 20$ & $\% 30$ & $\% 40$ & $\% 50$ & $\% 60$ & $\% 70$ & $\% 80$ & $\% 90$ \\
\hline \multicolumn{10}{|c|}{ 50-m Sürat (s) } \\
\hline Erkekler & 9.8 & 9.4 & 9.1 & 8.9 & 8.7 & 8.5 & 8.3 & 8.2 & 7.8 \\
\hline Kizlar & 10.0 & 9.5 & 9.2 & 9.0 & 8.8 & 8.6 & 8.4 & 8.2 & 8.0 \\
\hline \multicolumn{10}{|c|}{ Sağlık Topu Fırlatma (m) } \\
\hline Erkekler & 8.79 & 9.74 & 9.99 & 10.47 & 10.95 & 11.45 & 12.03 & 12.74 & 13.83 \\
\hline Kizlar & 7.23 & 7.99 & 8.55 & 9.02 & 9.46 & 9.91 & 10.38 & 10.93 & 11.70 \\
\hline \multicolumn{10}{|c|}{3 Adım Sıçrama (m) } \\
\hline Erkekler & 7.71 & 8.56 & 8.77 & 9.15 & 9.51 & 9.86 & 10.24 & 10.69 & 11.30 \\
\hline Kizlar & 7.53 & 8.08 & 8.48 & 8.82 & 9.14 & 9.46 & 9.80 & 10.20 & 10.75 \\
\hline \multicolumn{10}{|c|}{ Yıldız Çeviklik Koşusu (s) } \\
\hline Erkekler & 21.7 & 20.7 & 20.0 & 19.5 & 19.0 & 18.6 & 18.1 & 17.9 & 17.0 \\
\hline Kizlar & 22.1 & 21.2 & 20.6 & 20.1 & 19.7 & 19.3 & 18.8 & 18.3 & 17.6 \\
\hline \multicolumn{10}{|c|}{9 dk. Koşu (m) } \\
\hline Erkekler & 1261 & 1421 & 1461 & 1533 & 1600 & 1666 & 1738 & 1822 & 1938 \\
\hline Kizlar & 1189 & 1286 & 1355 & 1415 & 1471 & 1526 & 1586 & 1655 & 1752 \\
\hline
\end{tabular}

Tablo 3'te Golle ve diğerleri (2015) tarafından yapılan araştırmanın örneklemi içerisinde 12 yaş grubunda yer alan katılımcıların cinsiyet değişkenine göre $50 \mathrm{~m}$ sürat, sağlık topu firlatma, 3 adım sıçrama, yıldız çeviklik ve $9 \mathrm{dk}$. koşu testlerinden elde ettikleri yüzdelik değerlere yer verilmiştir. Avrupa genelinde norm olarak kabul edilen bu değerler ile araştırmamızın sonucunda elde ettiğimiz değerler karşılaştırılmış (Tablo 5) ve yorumlanmıştır.

\section{BULGULAR}

Araştırmanın bu bölümünde "IBM SPSS Statistics 22" istatistiksel analiz paket programı aracılığıyla gerçekleştirlen istatistiksel analizlerden elde edilen sonuçlara ait tablolara ve yorumlamalarına yer verilmiştir.

Tablo 4. Araştırma dahilinde uygulanan testlerden elde edilen skorlara ait ortalama ve standart sapma değerlerinin örneklemin yaş gruplarına göre dağılımı

\begin{tabular}{|c|c|c|c|c|c|c|c|c|c|c|c|}
\hline & & & & $\begin{array}{l}\text { Vücut } \\
\text { Ağırlığı } \\
\text { (kg) }\end{array}$ & $\begin{array}{c}\text { Boy } \\
\text { Uzunluğu } \\
(\mathbf{c m})\end{array}$ & $\begin{array}{c}\text { BKİ } \\
\left(\mathrm{kg} / \mathrm{m}^{2}\right)\end{array}$ & $\begin{array}{c}50 \text { m } \\
\text { Sürat } \\
(\mathrm{sn})\end{array}$ & $\begin{array}{c}\text { Sağlık } \\
\text { Topu } \\
\text { Firlatma } \\
\text { (m) }\end{array}$ & $\begin{array}{c}3 \text { Adım } \\
\text { Siçrama } \\
\text { (m) }\end{array}$ & $\begin{array}{c}\text { Yıldız } \\
\text { Çeviklik } \\
\text { Koşusu } \\
(\text { sn) } \\
\end{array}$ & $\begin{array}{c}9 \text { dk. } \\
\text { Koşu } \\
(\mathbf{m})\end{array}$ \\
\hline \multirow{12}{*}{$\begin{array}{c}\text { Yaş } \\
\text { Grupları }\end{array}$} & \multirow{4}{*}{$\begin{array}{c}12 \\
\text { Yaş }\end{array}$} & \multirow{2}{*}{ Erkekler } & Ort. & 51,00 & 152,00 & 21,75 & 9,77 & 7,40 & 3,55 & 23,21 & 1350,00 \\
\hline & & & $S$ & 15,71 & 7,00 & 4,97 &, 78 & 1,47 & 1,03 & 2,33 & 196,15 \\
\hline & & \multirow{2}{*}{ Kızlar } & Ort. & 44,50 & 151,33 & 19,29 & 10,71 & 5,58 & 3,43 & 24,51 & 990,83 \\
\hline & & & $S$ & 8,66 & 7,31 & 2,41 & 1,12 &, 51 &, 37 & 2,01 & 199,18 \\
\hline & \multirow{4}{*}{$\begin{array}{c}13 \\
\text { Yaş }\end{array}$} & \multirow{2}{*}{ Erkekler } & Ort. & 45,40 & 154,00 & 19,13 & 9,30 & 8,43 & 4,00 & 21,27 & 1257,00 \\
\hline & & & $S$ & 6,76 & 8,00 & 2,43 &, 84 & 1,46 & 1,11 & 2,60 & 143,59 \\
\hline & & \multirow{2}{*}{ Kızlar } & Ort. & 45,33 & 155,00 & 19,02 & 10,78 & 6,79 & 3,52 & 23,26 & 1185,83 \\
\hline & & & $S$ & 7,99 & 5,17 & 4,31 & 1,18 &, 79 &, 45 & 3,14 & 153,79 \\
\hline & \multirow{4}{*}{$\begin{array}{c}14 \\
\text { Yaş }\end{array}$} & \multirow{2}{*}{ Erkekler } & Ort. & 57,14 & 166,29 & 20,49 & 8,86 & 9,13 & 4,35 & 21,67 & 1342,86 \\
\hline & & & $S$ & 14,43 & 453 & 4,15 & ,97 & ,92 &, 83 & 1,22 & 168,14 \\
\hline & & \multirow{2}{*}{ Kızlar } & Ort. & 51,67 & 150,67 & 22,72 & 11,04 & 6,87 & 3,26 & 23,56 & 1191,67 \\
\hline & & & $S$ & 4,16 & 4,50 &, 61 & ,13 & ,69 &, 20 &, 80 & 209,66 \\
\hline
\end{tabular}

Tablo 4'te araştırmanın katılımcılarına ait performansa dayalı fiziksel uygunluklarının belirlenmesi amaciyla uygulanan testlerden elde edilen ortalama ve standart sapma değerleri ile 
birlikte vücut ağırlığı, boy uzunluğu ve BKİ skorlarına yer verilmiştir. Katılımcılar arasından 12 yaş grubuna ait motor uygunluk testlerinin uygulamasından elde edilen ortalama değerlere bakıldığında, erkek katılımcıların kızlara göre tüm testlerde daha iyi performans sergiledikleri gözlemlenmektedir. Ancak, Golle ve diğerlerine (2015) ait araştırmadan elde edilen ortalamaların yer aldığ 1 Tablo 2 incelendiğinde, 12 yaş grubuna ait motor uygunluk testlerinden elde edilen ortalama skorların araştımamızın 12 yaş grubu ortalama skorlarına göre hem erkek hem de kız katılımcılarda daha iyi düzeyde olduğu gözlemlenmektedir. Buna ek olarak Golle ve diğerleri'ne (2015) ait araştırmadan elde edilen 12 yaş grubu ortalama skorlarının, araştırmamızın 13 ve 14 yaş gruplarını oluşturan erkek ve kız katılımcıların motor uygunluk testlerinin uygulamalarından elde edilen ortalama skorlara göre yine daha iyi düzeyde olduğu; yanlızca $50 \mathrm{~m}$. sürat testi ortalama skorlarına göre araştımamızın 14 yaş grubu erkek katılımcılarının $50 \mathrm{~m}$. sürat testinde elde ettikleri ortalama skorun (Ort50 m. sürat $=8,86 \mathrm{sn}$ ) Golle ve diğerleri (2015)'ne ait araştırmanın 12 yaş grubu erkek katılımcılarının 50 m. sürat testi ortalama skoruna (Ort50 m. sürat=8.7 sn) göre daha iyi düzeyde olduğu gözlemlenmektedir.

Tablo 5. Araştırmadan elde edilen skorlar ile Golle ve diğerleri (2015) tarafindan gerçekleştirilen araştırmaya ait ortalama skorların Tek Örneklem t Testi yöntemiyle karşılaştırılması

\begin{tabular}{|c|c|c|c|c|c|}
\hline & Cinsiyet & Ort. & $\mathbf{S}$ & $\mathbf{p}$ & d \\
\hline \multirow{2}{*}{ Vücut Ağırlığg (kg) } & Erkekler & 52,00 & 12,91 & ,208 & 0,35 \\
\hline & Kizlar & 46,27 & 7,75 & ,987 & $-0,04$ \\
\hline \multirow{2}{*}{ Boy Uzunluğu (cm) } & Erkekler & 159,33 & 8,94 & ,291 & 0,29 \\
\hline & Kizlar & 152,67 & 5,96 &, 054 & $-0,56$ \\
\hline \multirow{2}{*}{ BKİ $\left(\mathrm{kg} / \mathrm{m}^{2}\right)$} & Erkekler & 20,29 & 3,68 &, 270 & 0,30 \\
\hline & Kizlar & 19,87 & 3,31 & ,277 & 0,30 \\
\hline \multirow{2}{*}{50 m Sürat (sn) } & Erkekler & 9,19 & ,91 &, 056 & 0,55 \\
\hline & Kizlar & 10,80 & ,98 &, $000 *$ & 2,10 \\
\hline \multirow{2}{*}{ Sağlık Topu Fırlatma (m) } & Erkekler & 8,55 & 1,32 &, $000 *$ & $-2,36$ \\
\hline & Kizlar & 6,32 & ,88 &, $000 *$ & $-4,03$ \\
\hline \multirow{2}{*}{3 Adım Sıçrama (m) } & Erkekler & 4,07 & ,95 &, $000 *$ & $-6,20$ \\
\hline & Kizlar & 3,43 & ,37 &, $000 *$ & $-16,26$ \\
\hline \multirow{2}{*}{ Yıldız Çeviklik Koşusu (sn) } & Erkekler & 21,84 & 1,97 &, $000 *$ & 1,49 \\
\hline & Kizlar & 23,82 & 2,33 &, $000 *$ & 1,92 \\
\hline \multirow{2}{*}{9 dk. Koşu (m) } & Erkekler & 1315,67 & 159,23 &, $000 *$ & $-1,83$ \\
\hline & Kizlar & 1109,00 & 197,16 &, $000 *$ & $-1,88$ \\
\hline
\end{tabular}

Ort. = Ortalama; $\mathrm{S}=$ Standart Sapma; $\mathrm{d}=$ etki değeri; ${ }^{*} \mathbf{p}<0.05$

Tablo 5'te araştırmamızın katılımcıları üzerinde uygulamaları gerçekleştirilen test ve ölçümlere ait skorların ortalama değerleri ile Golle ve diğerlerine (2015) ait araştırma sonuçlarından elde edilen ortalama değerlerinin Tek Örneklem t testi ile karşılaştırılmasından elde edilen standart sapma, p ve d değerlerine yer verilmiştir. Tabloya göre vücut ağrlığı, boy uzunluğu, BKİ değişkenleri ile erkekler $50 \mathrm{~m}$. sürat testi ortalamaları arasında anlamlı farklılıklar gözlemlenmemiştir (p>0,05). Yine Tablo 5 incelendiğinde, kızlar $50 \mathrm{~m}$. sürat testi ile birlikte hem erkek hem de kız katılımcıların sağlık topu fırlatma, 3 adım sıçrama, yıldız çeviklik koşusu ve $9 \mathrm{dk}$. koşusu testlerine ait ortalamaları arasında anlamlı düzeyde farklılıklar gözlemlenmiştir $(\mathrm{p}<0,05)$. 
Gülhan, Y.E. ve Akpınar, S. (2021). Covid-19 salgını sürecinde 10-14 yaş aralığındaki çocukların fiziksel uygunluk düzeylerinin belirlenmesi. Spor Bilimleri Araştırmaları Dergisi, 6(2), 365-383.

Tablo 6. Araştırma dahilinde uygulunan testlerden elde edilen skorlara ait ortalama değerlerin Tek Yönlü Varyans Analizi aracılığıyla yaş gruplarına göre karşılaştırılması

\begin{tabular}{|c|c|c|c|c|c|c|}
\hline Test Türü & Yaş Grubu & $N$ & Ort. & $S$ & $F$ & $p$ \\
\hline \multirow{3}{*}{$\begin{array}{l}\text { Vücut Ağırlığ } 1 \\
\text { (kg) }\end{array}$} & 12 yaş & 9 & 46,67 & 10,92 & \multirow{3}{*}{2,967} & \multirow{3}{*}{, 068} \\
\hline & 13 yaş & 11 & 45,36 & 7,08 & & \\
\hline & 14 yaş & 10 & 55,50 & 12,24 & & \\
\hline \multirow{3}{*}{$\begin{array}{l}\text { Boy Uzunluğu } \\
(\mathrm{cm})\end{array}$} & 12 yaş & 9 & 151,56 & 6,76 & \multirow{3}{*}{4,840} & \multirow{3}{*}{, $016 *$} \\
\hline & 13 yaş & 11 & 154,55 & 6,26 & & \\
\hline & 14 yaş & 10 & 161,60 & 8,66 & & \\
\hline \multirow{3}{*}{ BKİ $\left(\mathrm{kg} / \mathrm{m}^{2}\right)$} & 12 yaş & 9 & 20,11 & 3,36 & \multirow{3}{*}{0,95} & \multirow{3}{*}{0,396} \\
\hline & 13 yaş & 11 & 19,07 & 3,42 & & \\
\hline & 14 yaş & 10 & 21,16 & 3,57 & & \\
\hline \multirow{3}{*}{50 m Sürat (sn) } & 12 yaş & 9 & 10,40 & 1,07 & \multirow{3}{*}{1,294} & \multirow{3}{*}{,291 } \\
\hline & 13 yaş & 11 & 10,10 & 1,26 & & \\
\hline & 14 yaş & 10 & 9,51 & 1,32 & & \\
\hline \multirow{3}{*}{$\begin{array}{l}\text { Sağlık Topu } \\
\text { Firlatma (Sağ el) } \\
\text { (m) }\end{array}$} & 12 yaş & 9 & 6,80 & 1,23 & \multirow{3}{*}{5,580} & \multirow{3}{*}{, $009 *$} \\
\hline & 13 yaş & 11 & 7,93 & 1,82 & & \\
\hline & 14 yaş & 10 & 9,11 & 1,34 & & \\
\hline \multirow{3}{*}{$\begin{array}{l}\text { Sağlık Topu } \\
\text { Firlatma (Sol el) } \\
\text { (m) }\end{array}$} & 12 yaş & 9 & 5,58 & 1,46 & \multirow{3}{*}{5,920} & \multirow{3}{*}{, $007 *$} \\
\hline & 13 yaş & 11 & 7,16 & 1,28 & & \\
\hline & 14 yaş & 10 & 7,79 & 1,57 & & \\
\hline \multirow{3}{*}{$\begin{array}{l}3 \text { Adım Siçrama } \\
\text { (Sağ ayak) (m) }\end{array}$} & 12 yaş & 9 & 3,67 &, 55 & \multirow{3}{*}{1,043} & \multirow{3}{*}{,366 } \\
\hline & 13 yaş & 11 & 3,77 & ,76 & & \\
\hline & 14 yaş & 10 & 4,13 &, 85 & & \\
\hline \multirow{3}{*}{$\begin{array}{l}3 \text { Adım Siçrama } \\
\text { (Sol ayak) (m) }\end{array}$} & 12 yaş & 9 & 3,27 & ,68 & \multirow{3}{*}{1,446} & \multirow{3}{*}{,253 } \\
\hline & 13 yaş & 11 & 3,71 &, 88 & & \\
\hline & 14 yaş & 10 & 3,92 &, 89 & & \\
\hline \multirow{3}{*}{$\begin{array}{l}\text { Y1ldız Çeviklik } \\
\text { Koşusu (sn) }\end{array}$} & 12 yaş & 9 & 24,08 & 2,07 & \multirow{3}{*}{1,924} & \multirow{3}{*}{, 166} \\
\hline & 13 yaş & 11 & 22,35 & 2,96 & & \\
\hline & 14 yaş & 10 & 22,24 & 1,40 & & \\
\hline \multirow{3}{*}{9 dk. Koşu (m) } & 12 yaş & 9 & 1110,56 & 258,19 & \multirow{3}{*}{2,129} & \multirow{3}{*}{, 138} \\
\hline & 13 yaş & 11 & 1218,18 & 146,48 & & \\
\hline & 14 yaş & 10 & 1297,50 & 184,25 & & \\
\hline
\end{tabular}

Ort. = Ortalama; S = Standart Sapma; F = Tek Yönlü Varyans Analizi İstatistik Değeri; *p<0.05

Tablo 6'da araştırma dahilinde uygulanan test ve ölçümlerden elde edilen ortalama skorların katılımcılara ait yaş gruplarına göre Tek Yönlü Varyans Analizi aracılığıyla karşılaştırılması sonucu elde edilen ortalama, standat sapma, F istatistiği ve p değeri skorlarına yer verilmiştir. Tablo incelendiğinde araştırmanın bağımlı değişkenlerinden boy uzunluğu, sağ ve sol el sağlık topu firlatma testlerinden elde edilen yaş gruplarına ait ortalama skorlar arasında anlamlı düzeyde farklılık gözlemlenmektedir $(\mathrm{p}<0,05)$. 
Gülhan, Y.E. ve Akpınar, S. (2021). Covid-19 salgını sürecinde 10-14 yaş aralığındaki çocukların fiziksel uygunluk düzeylerinin belirlenmesi. Spor Bilimleri Araştırmaları Dergisi, 6(2), 365-383.

Tablo 7. Sağ - sol el sağlık topu firlatma testlerine ait ortalama skorların çoklu karşılaştırma testleri aracılığıyla yaş gruplarına göre karşılaştırılması

\begin{tabular}{|c|c|c|c|c|c|}
\hline Bağımlı değişken & & (I) Yaş Grupları & (J) Yaş Grupları & Ort. Fark (I-J) & $p$ \\
\hline \multirow{4}{*}{$\begin{array}{l}\text { Sağlık Topu Firlatma Skoru } \\
\text { (Sağ El) }\end{array}$} & \multirow{6}{*}{ Scheffe } & \multirow{2}{*}{12} & 13 & $-1,12$ & 268 \\
\hline & & & 14 & $-2,31^{*}$ &, $009 *$ \\
\hline & & \multirow{2}{*}{13} & 12 & 1,12 & ,268 \\
\hline & & & 14 & $-1,18$ & ,217 \\
\hline \multirow{8}{*}{$\begin{array}{l}\text { Sağlık Topu Fırlatma Skoru } \\
\text { (Sol El) }\end{array}$} & & \multirow{2}{*}{14} & 12 & $2,31^{*}$ &, $009 *$ \\
\hline & & & 13 & 1,18 & ,217 \\
\hline & \multirow{6}{*}{ Scheffe } & \multirow{2}{*}{12} & 13 & $-1,58$ &, 067 \\
\hline & & & 14 & $-2,21^{*}$ &, $009 *$ \\
\hline & & \multirow{2}{*}{13} & 12 & 1,58 & ,067 \\
\hline & & & 14 &,- 63 & 604 \\
\hline & & \multirow{2}{*}{14} & 12 & $2,21^{*}$ &, $009 *$ \\
\hline & & & 13 &, 63 & ,604 \\
\hline
\end{tabular}

Tablo 7'de yer verilen araştıma örnekleminin yaş grupları arasındaki farklılığın tespit edilmesi amacıyla gerçekleştirilen çoklu karşılaştrıma testine ait sonuçlar incelendiğinde, hem sağ hem de sol elle sağlık topu firlatma testlerinde 12 yaş grubu ile 14 yaş grubu katılımcıların ortalamalarına ait skorları arasında anlamlı bir farklılık gözlemlenmiştir $(p<0,05)$. Tablodan hareketle yaş gruplarının sağlık topu firlatma testlerine ait ortalama değerler incelendiğinde 14 yaş grubu ortalama değerlerinin 12 yaş grubu ortalama değerlerine göre sağ elde $\cong 2,31 \mathrm{~m}$., sol elde ise $\cong 2,21 \mathrm{~m}$. daha fazla olduğunu ve buna bağlı olarak daha iyi bir performans sergilediklerini ifade etmek mümkündür.

\section{TARTIŞMA VE SONUÇ}

Covid-19 salgını sürecinde 10-14 yaş aralığındaki çocukların fiziksel uygunluk düzeylerinin belirlenmesi amacıyla gerçekleştirilen bu araştırmada, araştırmanın örneklemi üzerinde uygulaması gerçekleştirilen performansa dayalı uygunluk testlerinden elde edilen verilerin, Golle ve diğerleri (2015) tarafından gerçekleştirilen ve bu konuda Avrupa genelindeki durumu ortaya koyduğu düşünülen "9-12 Yaş Arasındaki Alman Çocukların Fiziksel Uygunluk Yüzdelikleri: Boylamsal Bir Çalışmadan Elde Edilen Bulgular” başlıklı araştırmadan elde edilen sonuçlarla karşılaştırmalı olarak yorumlanmıştır. Yapılan karşılaştırmalar sonucunda vücut ağırlığı, boy uzunluğu, BKİ ve erkekler $50 \mathrm{~m}$. sürat testi ortalama skorları arasında anlamlı düzeyde farklılık bulunmazken ( $>>0,05)$, kızlar $50 \mathrm{~m}$. sürat testi ve hem kız hem de erkeklere ait sağlık topu fırlatma, 3 adım sıçrama, yıldız çeviklik koşusu ve $9 \mathrm{dk}$. koşusu testlerine ait ortalamalar arasında anlamlı düzeyde farklılıklar bulunmuştur $(p<0,05)$.

Golle ve diğerleri (2015) tarafından gerçekleştirilen çalışmaya ait yüzdelik dilimlerin yer aldığı Tablo 3 'teki verilerle araştımamızın katılımcılarına ait ortalama skorlar karşılaştırıldığında;

- 12 yaş grubu erkeklerin ortalama olarak $50 \mathrm{~m}$. sürat ve $9 \mathrm{dk}$. koşusu testlerinde $\% 10$ - \% 20'lik dilimler arasında, yani ortalama değer olan \%50'lik değerin çok altında olduğu,

- 13 yaş grubu erkeklerin ortalama olarak 50 m. sürat koşusu testinde \%20 - \%30'luk, 9 dk. koşusu ve yıldız çeviklik koşusu testlerinde ise \%10 - \% 20'lik dilimler arasında, yani ortalama değer olan \%50'lik değerin çok altında olduğu, 
- 14 yaş grubu erkeklerin ortalama olarak $50 \mathrm{~m}$. sürat testinde $\% 50$ - \%60’lık, sağlık topu firlatma, yıldız çeviklik koşusu ve $9 \mathrm{dk}$. koşusu testlerinde \%10 - \%20' lik dilimler arasında, yani ortalama değer olan \%50'lik değerin çok altında olduğu,

- 14 yaş grubu kızların ortalama olarak $9 \mathrm{dk}$. koşusu testinde \%10 - \% 20'lik dilimler arasında, yani ortalama değer olan $\% 50$ 'lik değerin çok altında olduğu gözlemlenmektedir.

Katılımcılara ait yukarıda verilen ortalama skorların haricindeki diğer ortalama skorlar incelendiğinde ise, Tablo 3'te verilen yüzdelik değerlerden hareketle genel olarak \%10'luk dilime ait ortalama değere yakın yada bu değerin altında seyrettikleri tespit edilmiştir.

Araştırmamızın yaş gruplarına ait sağlık topu firlatma testi ortalamalarının karşılaştırılmasııdan elde edilen sonuçlar incelendiğinde, 12 yaş grubu ile 14 yaş grubu katılımcıların hem sağ hem de sol elle sağlık topu firlatma testinden elde ettikleri ortalama skorlar arasında anlamlı düzeyde farklılık bulunmuştur $(\mathrm{p}<0,05)$. Ortalama değerleden hareketle 14 yaş grubu katılımcıların hem sağ hem de sol elle sağlı topu firlatma testinde 12 yaş grubundan anlamlı derecede iyi bir performans sergilediğini ifade etmek mümkündür. Gelişimsel olarak bu sonuç anlamlı bulunmaktadır.

Golle ve diğerleri (2015) tarafından yapılan çalışmadan elde edilen sonuçlar incelendiğinde, yaş artışı ile birlikte katılımcıların sahip olduğu performansa dayalı fiziksel uygunluk düzeylerinin tespitinde kullanılan testlerden elde dilen ortalama değerlerde doğrusal bir artış gözlemlenmektedir (Tablo 2 ve Tablo 3). Ancak araştırmamızdan elde ettiğimiz sonuçlar, Golle ve diğerleri (2015) tarafindan gerçekleştirilen çalışmaya ait sonuçlarda gözlemlediğimiz bu durumla ters düşmektedir. Bu durumun, pandemi sürecinde zorunluluk haline gelen hareketsiz yaşam tarzının bireylerin fiziksel uygunluk parametrelerinde meydana getireceği olası düşüşten kaynaklandığını ifade etmek mümkündür.

Araştırmamızın örneklemini oluşturan katılımcıların içerisinde bulundukları yaş aralığı göz önünde bulundurulduğunda gelişim süreçlerinin devam ettiğini söylemek mümkündür. $\mathrm{Bu}$ süreçte çocukların sahip oldukları fiziksel uygunluk parametrelerinde gelişim sürecine bağlı olarak birtakım farklılaşmaların oluşması olasıdır.

Çocuklarda ve ergenlik çağında bulunan bireylerde performansa dayalı fiziksel yeterlilikler tespit edilirken büyüme sürecinin bu yeterlilikler üzerindeki etkileri yadsınamaz bir gerçektir (Kale ve Kara, 1998). Ergenlik dönemi öncesine ait temel motorik özelliklere ve motor performans düzeylerine bakıldığında cinsiyet değişkenine göre anlamlı düzeyde herhangi bir farklılaşmanın olmadığını, ergenlik dönemi ile birlikte erkeklerin bahsedilen bu niteliklerde kızlara göre belirgin oranda gelişim göstererek daha iyi düzeye eriştikleri gözlemlenmiştir. Dahası, ergenlik döneminin bireyler üzerindeki en önemli etkilerinden biri olan hormonal hareketlilik ve buna bağlı gerçekleşen birtakım farklılaşmaların, erkeklerde başta kuvvet olmak üzere birçok fiziksel uygunluk parametresinde kızlara oranla daha belirgin bir artışın yaşanmasına sebep olmaktadır (Muratlı, 1997).

7-12 yaş aralı̆̆ındaki kız-erkek toplam 203 ilköğretim düzeyinde öğrenim gören öğrencinin katılım gösterdiği ve Eurofit Test Bataryası aracılığıyla yaş gruplarına göre motor uygunluk parametrelerinin tespit edildiği bir araştırma sonucunda, 10 yaşına kadar cinsiyet değişkenine göre motor uygunluk parametrelerinden elde edilen sonuçların benzer oranda farklılaştığı, fakat 
ilerleyen yaşlarda erkek çocukların kızlara göre anlamlı bir atılım sergileyerek daha fazla gelişim gösterdiği gözlemlenmiştir (Erikoğlu vd., 2009). Bu çalışmaya benzer olarak; Avrupa genelinde 12-18 yaş aralığında gençlerle yapılan bir araştırmada da, erkek katılımcıların kızlara göre birçok fiziksel uygunluk parametresinde daha iyi performans sergiledikleri sonucuna ulaşılmıştır (Ortega vd., 2011). Cinsiyet değişkenine göre sedanter gençlerden elde edilen motor uygunluk parametrelerindeki sonuçlar (Saygın, Karacabey ve Saygın, 2011), spor yapan (atletizm ve badminton) gençlerin sonuçları ile paralellik göstermektedir (Arabacı, 2007; Yanci, Camara, Vizcay ve Young, 2016). Yapılan bu araştırmada da, cinsiyet değişkenine göre erkeklerin kızlara göre birçok motor uygunluk parametrelerinde (kuvvet, sürat, çeviklik ve dayanıklılık) daha iyi performans sergiledikleri gözlemlenmiştir.

Çalışmamıza konu olan örneklemin araştırma dahilinde gerçekleştirdiğimiz motor uygunluk testlerinden elde ettiği sonuçlar incelendiğinde (Tablo 6), hem yaş artışına hem de cinsiyet değişkenine bağlı olarak göstermiş oldukları performansın ve sonucunda elde ettikleri skorların doğrusal olarak artış gösterdiği gözlemlenmektedir. Bu yönüyle çalışmamızdan elde edilen sonuçlar ile literatürde yer alan benzer çalışmalardan (Guessogo vd., 2020; Kasović, Štefan ve Petrić, 2021; Özgür, 2020; Pekel vd., 2007; Salimov, 2021; Saygın vd., 2011) elde edilen sonuçların birbiriyle paralellik gösterdiğini ifade etmek mümkündür.

Birtakım sebeplerden dolayı yaşam tarzında gerçekleşen ani değişikliklerin ve zorunlu izolasyon sürecinin, insanlar üzerinde meydana getirdiği anksiyeteye bağlı olarak stres, kayg1 ve korku kaynaklı aşırı besin tüketimi durumunun oluşabileceği ve bu hususta gerekli önlemlerin alınması gerektiğini ifade eden çalışmalar mevcuttur (Rice vd., 2016; Schyns, Roefs ve Jansen, 2020). Şahin (2021), karantina döneminde özellikle yüksek karbonhidrat oranına sahip gıdaların normal dönemle aynı düzeyde tüketilmesinin, bireylerde enerji dengesinin bozulmasına bağlı olarak vücut ağırlığında olumsuz yükselişlere sebep olabileceğini ifade etmiştir.

Yapılan araştırmalar beslenme ve fiziksel aktivite düzeyinin, özellikle çocukluk çağında bulunan bireylerin genel sağlı̆̆ ve fiziksel uygunluk düzeyleri açısından önemli unsurlar olduğunu belirtmektedir. Ayrıca, bu çalışmalar fiziksel aktivite düzeyi, beslenme alışkanlıkları, beslenme kalitesi ve alınan günlük enerji miktarı ile fiziksel uygunluk düzeyi arasında anlamlı ilişkilerin olduğunu ifade etmektedir (Grund vd., 2000; Jeszka, Zielke ve Bajerska, 2000; Vandongen vd., 1995). Covid-19 salgını sürecinde ise, sadece sedanter bireylerin değil aynı zamanda sporcuların da hazır gıda tüketimine yöneldikleri ve sağlıksız beslenme taktikleri edindikleri tespit edilmiştir (Roberts, Gill ve Sims, 2020). Beslenme alışkanlıklarındaki farklılaşmanın sağllk ve fiziksel uygunluk bileşenleri üzerinde anlamlı farkl1lıklara sebep olduğu belirtilmiştir (Perry vd., 2002). Böylelikle Covid-19 salgını sürecindeki sağlıksız beslenmenin fiziksel uygunluk parametrelerini olumsuz bir şekilde etkileyebilecektir. Beslenme durumu ile fiziksel uygunluk arasındaki ilişkiyi konu edinen araştırmaların sonuçlarından hareketle; araştırmamızın katılımcılarına ait boy uzunluğu ve vücut ağırlığı skorlarına bağlı olarak elde edilen BKİ skorlarının, pandemi sürecinde gerçekleştiği düşünülen beslenme durumu ve kalitesindeki olumsuz yönde gerçekleşen değişimlerin bir göstergesi olarak kabul edilebilir. Bu duruma paralel olarak katılımcıların performansa dayalı fiziksel uygunluk parametrelerinin de olumsuz yönde etkilendiğini ifade etmek mümkündür. 
Fiziksel aktiviteye katılımın belirgin düzeyde azaldığı görülen pandemi sürecinde, bu durumdan en çok etkilenen ülkelerden birisi olan İspanya'da gerçekleştirilen ve karantina uygulamasının fiziksel aktiviteye katılım düzeyinde gerçekleştirdiği değişimleri konu alan araştırmaya ülke genelinden 18-64 yaş aralığındaki sağlıklı 3800 birey katılım göstermiştir. Araştırmadan elde edilen sonuç, karantina sürecinde fiziksel aktiviteye katılımın önemli ölçüde azaldığını ve en büyük azalmanın fiziksel aktivite düzeyi en yüksek bireylerde yaşandığını ortaya koymuştur. Ayrıca, fiziksel aktivite düzeyine göre erkeklerin yüksek şiddetli fiziksel aktivitelere katılım oranında kadınlara göre daha fazla düşüş yaşandığı belirtilmiştir (Castañeda-Babarro, Arbillaga-Etxarri, Gutiérrez-Santamaría ve Coca, 2020). Pandemi sürecinin fiziksel aktiviteye katılım düzeyini olumsuz yönde etkileyerek hareketsizliği tetikleyen getirilerinin yer aldığı listeye, pandemi öncesi döneme oranla belirgin ölçüde artış gösterdiği gözlemlenen teknoloji kullanım sıklığı ve süresi eklenebilir. 4-17 yaş aralığındaki toplam 1711 Alman çocuğun ve gencin katılımıyla gerçekleştirilen araştırmada, katılımcıların pandemi öncesi dönem ile pandemi sürecindeki ekran karşısında geçirdikleri süreler ile fiziksel aktiviteye katılım düzeyleri arasındaki ilişki incelenmiştir. Bu araştırmadan elde edilen sonuçlara göre; katılımcıların pandemi sürecinde pandemi öncesi döneme oranla ekran başında geçirdikleri sürenin arttığı ve buna bağlı olarak fiziksel aktiviteye katılım düzeylerinde azalamanın meydana geldiği gözlemlenmiştir (Schmidt vd., 2020).

Sonuç olarak, araştırmamızın amacı doğrultusunda gerçekleştirdiğimiz motor uygunluk testlerinden elde edilen ortalama skorlar ile Golle ve diğerleri (2015) tarafindan gerçekleştirilmiş araştırmadan elde edilen sonuçlar karşılaştırıldığında, araştımamızın örneklemine ait performansa dayalı fiziksel uygunluk düzeylerinin oldukça düşük seviyelerde olduğu gözlemlenmiştir. Bu durumun başlıca sebeplerinin;

- Pandemi döneminde alınan tedbirlerin zorunlu kıldığı hareketsiz yaşam ve buna bağ 1 olarak fiziksel aktivite düzeyindeki belirgin azalma,

- Beslenme durumları ve kalitesi üzerinde pandemi dönemiyle birlikte gerçekleşen olumsuz farklılaşmalar olduğu düşünülmektedir.

\section{ÖNERİLER}

Araştırmadan elde edilen sonuçlardan hareketle;

- Covid 19 salgını sürecinin insanlar üzerinde zorunlu kıldığı hareketsizliğin önüne geçilebilmesi amacıyla kapalı alanlarda geçirilen izolasyon süresince gerçekleştirilebilecek fiziksel aktivite alternatiflerinin artırılarak bireylerin bu konuda daha bilinçli hale gelebilmesi için gerekli AR-GE ve bilgilendirme çalışmaları gerçekleştirilmelidir.

- Pandemi süreciyle birlikte bireyleri hareketsiz kılan en önemli etkenlerin başında teknoloji kulllanım süresindeki artış gelmektedir. İzalosyon tedbirleri doğrultusunda uzun bir süre boyunca evlerinde vakit geçirmek durumunda kalan bireyler zamanlarının büyük bölümünü cep telefonu, tv, bilgisayar, oyun konsolu vb. teknolojik araç-gereçlerle harcama alışkanlığ edinmişlerdir. Bu olumsuz alışkanlıkların sebep olduğu hareketsizliğin önüne geçebilmek için ebeveynlerin öncülüğünde ekran süresini azaltıcı alternatif etkinlikler oluşturulmalı ve tüm aile bireylerinin düzenli olarak bu etkinliklere katılımı teşvik edilmelidir. 
- Pandemi sürecinin zorunlu kıldığı hareketsizlikle birlikte farklılaşan beslenme durumları, bireyleri kilo problemiyle karşı karşıya bırakmıştır. $\mathrm{Bu}$ sebeple bireyler sağlıksız besinlerden ve beslenme alışkanlıklarından uzak durarak pandemi öncesi döneme göre beslenmelerine daha çok dikkat etmelidirler.

- Eğitim-öğretimde uzaktan eğitimi zorunluluk haline dönüştüren pandemi süreci, öğrencileri hareketli kılan tüm okul içi ve dışı faaliyetleri durma noktasına getirmiştir. Bu süreçte Milli Eğitim Bakanlığınca zaman zaman alınan tedbirler doğrultusunda yüz yüze eğitim kararı alınmış olsa da beden eğitimi ve spor dersi süreç boyunca uzaktan eğitimle sürdürülmüştür. $\mathrm{Bu}$ sebeple tam anlamıyla yüz yüze eğitim kararı alındığı takdirde okul içi ve dışı çeşitli fiziksel aktivite, egzersiz ve spor etkinliklerinin düzenlenerek öğrencilerin pandemi süreci sebebiyle artan hareket ihtiyacı ilgililerce ivedilikle telafi edilmelidir.

Çıkar Çatışması: “Covid-19 Salgını Sürecinde 10-14 Yaş Aralığındaki Çocukların Fiziksel Uygunluk Düzeylerinin Belirlenmesi” başlıklı çalışma kapsamında herhangi bir şahsi ve mali çıkar çatışması bulunmamaktadır.

Araştırmacıların Katkı Oranı Beyanı: Araştırma Dizaynı - SA, YEG; Verilerin Toplanması - YEG; İstatistiksel Analiz - SA, YEG; Makalenin Hazırlanması - YEG, SA.

\section{Etik Kurul İzni ile İlgili Bilgiler}

Kurul Adı: Nevşehir Hacı Bektaş Veli Üniversitesi Girişimsel Olmayan Klinik Araştırmalar Etik Kurul Başkanlığ

Tarih: 23.10.2020

Sayı/Karar No: 2020.19.277 
Gülhan, Y.E. ve Akpınar, S. (2021). Covid-19 salgını sürecinde 10-14 yaş aralığındaki çocukların fiziksel uygunluk düzeylerinin belirlenmesi. Spor Bilimleri Araştırmaları Dergisi, 6(2), 365-383.

\section{KAYNAKLAR}

Akpınar, S. (2020). Nevü söyleşiler: Fiziksel aktivite ve hareketli-hareketsiz yaşam. 25 Mayıs 2020. https://sistem.nevsehir.edu.tr/.

Arabacı, R. (2007). 15 yaş altı kız ve erkek badmintoncularının fiziksel uygunluklarının karşılaştırılması. Sport Sciences, 3(1), 1-10.

Balcı, Ş.S., Pekel, H.A., Karakuş, S., Pepe, H., Revan, S. ve Bağcı, E. (2008). 9-11 yaş grubu ilköğretim öğrencilerinin performansla ilgili fiziksel uygunluklarının değerlendirilmesi. Selçuk Üniversitesi Sosyal Bilimler Enstitüsü Dergisi, 20, 103-08.

Bös, K., Schlenker, L., Büsch, D., Lämmle, L., Müller, H., Oberger, J. \& Tittlbach, S. (2009). Deutscher Motorik Test 6-18:(DMT 6-18). Vol: 186, Hamburg: Czwalina.

Burtscher, J. \& Burtscher, M. (2020). Run for your life: Tweaking the weekly physical activity volume for longevity. British Journal of Sports Medecine, 54(13), 759-760. http://dx.doi.org/10.1136/bjsports-2019101350

Burtscher, J., Burtscher, M. \& Millet, G.P. (2020). (Indoor) Isolation, stress and physical inactivity: Vicious circles accelerated by Covid-19? Scandinavian Journal of Medicine \& Science in Sports, 30(8), 1544-1545. https://doi.org/10.1111/sms.13706

Castañeda-Babarro, A., Arbillaga-Etxarri, A., Gutiérrez-Santamaría, B. \& Coca, A. (2020). Physical activity change during covid-19 confinement. International Journal of Environmental Research and Public Health, 17(18), 6878.

Council of Europa (2011). Sport testing physical fitness eurofit experimental battery provisional handbook 1983. www.bitworks-engineering.co.uk. March 2011; 3, Strasbourg.

Crisafulli, A. \& Pagliaro, P. (2020). Physical activity/inactivity and covid-19. European Journal of Preventive Cardiology, In press, 1-4 https://doi.org/10.1177/2047487320927597

Darilgen, A. (2006). Tekerlekli sandalye basketbol sporu yapanlarda fiziksel uygunluğunun değerlendirilmesi. Yüksek Lisans Tezi, Abant İzzet Baysal Üniversitesi, Sağlık Bilimleri Enstitüsü, Bolu.

Erikoğlu, G., Özkamçı, H., Golmoghanı, N., Suveren, C., Tot, T., Şahin, N., Selçuk, Z., Zorba, E. ve Atalay Güzel, N. (2009). 7-12 yaş çocuklarda cinsiyet ve yaş gruplarına göre eurofit test bataryası ile performans parametrelerinin değerlendirilmesi. Gazi Beden Eğitimi ve Spor Bilimleri Dergisi, 14(4), 49-64.

Erkal E., Ses A., Aydın S., Çalışkan D. (2020). Covid-19'un toplumda yayılımını önlemeye yönelik ilaç dışı halk sağlığı önlemleri. ESTÜDAM Halk Să̆lı̆̆l Dergisi, 5, 79-95.

Golle, K., Muehlbauer, T., Wick, D. \& Granacher, U. (2015). Physical fitness percentiles of german children aged 9-12 years: findings from a longitudinal study. Plos One, 10(11). https://doi.org/10.1371/journal.pone.0142393

Grund, A., Dilba, B., Forberger, K., Krause, H., Siewers, M., Rieckert, H. \& Müller, M. J. (2000). Relationships between physical activity, physical fitness, muscle strength and nutritional state in 5- to 11-year-old children. European Journal of Applied Physiology, 82(5), 425-438. https://doi.org/10.1007/s004210000197.

Guessogo, W., Mekoulou Ndongo, J., Assomo-Ndemba, P., Hamadou, A., Biassi, O., Tsobgny-Panka, C., Mbah, G., Honoré Mandengue, S. \& Temfemo, A. (2020). Gender differences in physical fitness among cameroonian school children aged 10 to 15 years in yaounde city. International Journal of School Health, 7(3), 45-54. doi: 10.30476/intjsh.2020.86621.1086.

Jeszka, J., Zielke, M. \& Bajerska, J. (2000). Evaluation of nutritional habits, nutritional status and physical performance in selected group of adolescents. Medycyna Wieku Rozwojowego, 4(3 Suppl 1), 65-75.

Kale, R., ve Kara, E. (1998). Spor, kültür ve modern endüstri dünyası. 5. Uluslararası Spor Bilimleri Kongresi. Ankara. 
Gülhan, Y.E. ve Akpınar, S. (2021). Covid-19 salgını sürecinde 10-14 yaş aralığındaki çocukların fiziksel uygunluk düzeylerinin belirlenmesi. Spor Bilimleri Araştırmaları Dergisi, 6(2), 365-383.

Karasar, N. (2012). Bilimsel araştırma yöntemi (24. baskı). Ankara: Nobel Yayıncılık.

Kasović, M., Štefan, L. \& Petrić, V. (2021). Secular trends in health-related physical fitness among 11-14-yearold croatian children and adolescents from 1999 to 2014. Scientific Reports, 11(1), 11039. https://doi.org/10.1038/s41598-021-90745-y.

Kayıhan, G. (2007). Ankara polis koleji öğrencilerinin fiziksel uygunluk düzeylerinin değerlendirilmesi. Yüksek Lisans Tezi, Ankara Üniversitesi, Sağlık Bilimleri Enstitüsü, Ankara.

Kayıhan, G. ve Ersöz, G. (2010). Türk polis teşkilatında vücut kompozisyonunun fiziksel uygunluk ve performans açısından değerlendirilmesi. Polis Bilimleri Dergisi, 12(3), 67-82.

Koşar, Ş.N., Kin, A. \& Aşçı, F.H. (1998). 10 haftalık fiziksel etkinlik programına katılım fiziksel uygunluğa etkisi. Hacettepe Spor Bilimleri Dergisi, 9(2), 3-11.

Memiş, A.U. (2007). Çocukluk ve ergenlikteki fiziksel aktivite deneyimleri ile yetişkinlikteki fiziksel aktivite düzeyi arasındaki ilişki. Doktora Tezi, Gazi Üniversitesi, Eğitim Bilimleri Enstitüsü, Ankara.

Mikkelsen, K., Stojanovska, L., Polenakovic, M., Bosevski, M. \& Apostolopoulos, V. (2017). Exercise and mental health. Maturitas, 106, 48-56. https://doi.org/10.1016/j.maturitas.2017.09.003.

Muratlı, S. (1997). Antrenman bilimi ışı̆̆ı altında çocuk ve spor. Ankara: Bağırgan Yayın Evi.

Nieman, D.C. \& Wentz, L.M. (2019). The compelling link between physical activity and the body's defense system. Journal of Sport and Health Science, 8(3), 201-217. https://doi.org/10.1016/j.jshs.2018.09.009.

Ortega, F.B., Artero, E.G., Ruiz, J.R., Espana-Romero, V., Jimenez-Pavon, D., Vicente-Rodriguez, G. et al. (2011). Physical fitness levels among European adolescents: the helena study. British Journal of Sports Medicine, 45(1), 20-29. https://doi.org/10.1136/bjsm.2009.062679.

Ortega, F.B., Ruiz, J.R., Castillo, M.J \& Sjöström, M. (2008). Physical fitness in childhood and adolescence: a powerful marker of health. International Journal of Obesity (2005), 32, 1-11. https://doi.org/10.1038/sj.ijo.0803774.

Özer, D.S. ve Özer, M.K. (1998). Çocuklarda motor gelişim. Ankara: Nobel Yayıncılık.

Özer, M.K. (2006). Fiziksel uygunluk (2. Baskı). Ankara: Nobel Yayın Dağıtım.

Özgür, B. (2020). 10-14 yaş türk badminton oyuncularının bazı antropometrik ve motorik performans özellikleri. Spor Hekimliği Dergisi, 55(3), 222-230.

Peçanha, T., Goessler, K. F., Roschel, H. \& Gualano, B. (2020). Social isolation during the covid-19 pandemic can increase physical inactivity and the global burden of cardiovascular disease. American Journal of Physiology. Heart and Circulatory Physiology, 318(6), H1441-H1446. https://doi.org/10.1152/ajpheart.00268.2020

Pekel, H. A., Balci, Ş. S., Arslan, Ö., Bağci, E., Aydos, L., Tamer, K. ve Kalemoğlu, Y. (2007). Atletizm yapan çocukların performansla ilgili fiziksel uygunluk test sonuçlarının ve bazı antrepometrik özelliklerinin değerlendirilmesi. Kastamonu Ĕ̆itim Dergisi, 15(1), 427-438.

Perry, A.C., Okuyama, T., Tanaka, K., Signorile, J., Kaplan, T.A. \& Wang, X. (2002). A comparison of health and fitness-related variables in a small sample of children of japanese descent on 2 continents. Archives of Pediatrics and Adolescent Medicine, 156(4), 362-368. https://doi.org/10.1001/archpedi.156.4.362

Polat, Ç. (2009). 12-14 yaş ĕgitilebilir zihinsel engelli çocukların fiziksel aktivite yoğunluğunun fiziksel uygunluk düzeylerine etkisi. Yüksek Lisans Tezi, Erciyes Üniversitesi, Sağlık Bilimleri Enstitüsü, Kayseri.

Rice, S.M., Purcell, R., De Silva, S., Mawren, D., McGorry, P.D. \& Parker, A.G. (2016). The mental health of elite athletes: a narrative systematic review. Sports Medicine (Auckland, N.Z.), 46(9), 1333-1353. https://doi.org/10.1007/s40279-016-0492-2.

Roberts, C., Gill, N. \& Sims, S. (2020). The influence of covid-19 lockdown restrictions on perceived nutrition habits in rugby union players. Frontier in Nutrition, 7, 589737. doi: 10.3389/fnut.2020.589737. 
Gülhan, Y.E. ve Akpınar, S. (2021). Covid-19 salgını sürecinde 10-14 yaş aralığındaki çocukların fiziksel uygunluk düzeylerinin belirlenmesi. Spor Bilimleri Araştırmaları Dergisi, 6(2), 365-383.

Şahin, T. (2021). Covid-19 pandemi sürecinde sporcu beslenmesi: Beslenme alışkanlığı değişimleri ve öneriler. Çanakkale Onsekiz Mart Üniversitesi Spor Bilimleri Dergisi, 4(1), 1-9.

Şahiner, İ. (2009). Çocuklarda uygulanan farklı otur-uzan esneklik testlerinin karşılaştırılması. Yüksek Lisans Tezi, Selçuk Üniversitesi, Sağlık Bilimleri Enstitüsü, Konya.

Salimov, G'. M. (2021). 7-10 yaş erkek ve kız çocuklarinin hazırlık ve fiziksel gelişiminin gösterge ve analizleri. International Journal on Economics, Finance and Sustainable Development, 3(5), 59-69. https://doi.org/10.31149/ijefsd.v3i5.1894.

Şardan, Y.Ç. (2008). Hastane salgınlarının incelenmesi. IÜ Cerrahpaşa Tıp Fakültesi Sürekli Tıp Eğitimi Etkinlikleri Sempozyum Dizisi, 60(53), 61.

Saygın, E., Karacabey, K. ve Saygın, Ö. (2011). Çocuklarda fiziksel aktivite ve fiziksel uygunluk unsurlarının araştırılması. Uluslararası Insan Bilimleri Dergisi, 8(2), 921-35.

Schmidt, S., Anedda, B., Burchartz, A., Eichsteller, A., Kolb, S., Nigg, C., Niessner, C., Oriwol, D., Worth, A. \& Woll, A. (2020). Physical activity and screen time of children and adolescents before and during the COVID-19 lockdown in Germany: a natural experiment. Scientific Reports, 10(1), 21780. https://doi.org/10.1038/s41598-020-78438-4.

Schyns, G., Roefs, A. \& Jansen, A. (2020). Tackling sabotaging cognitive processes to reduce overeating; expectancy violation during food cue exposure. Physiology \& Behavior, 222, 112924. https://doi.org/10.1016/j.physbeh.2020.112924.

Sönmez, E. (2006). Adölesan dönemi voleybolcu çocukların antropometrik ölçümlerinin belirlenmesi ve sedanter çocuklarla karşılaştırılması. Yüksek Lisans Tezi, Fırat Üniversitesi, Sağlık Bilimleri Enstitüsü, Elâzı̆̆.

Stark, G. (2000). Jugend trainiert für Olympia: Wettkampfprogramm für Grundschulen im Land Brandenburg. Jugend und Sport, Potsdam: Ministerium für Bildung.

T.C. Sağlı Bakanlığı (2020a). Covid-19 nedir? Covid-19 Bilgilendirme Platformu. https://covid19.saglik.gov.tr/TR-66300/covid-19-nedir-.html, Erişim tarihi: 03 Haziran 2020.

T.C. Sağlık Bakanlığı (2020b). Pandemi. Covid-19 bilgilendirme platformu. https://covid19.saglik.gov.tr/TR66494/pandemi.html, Erişim tarihi: 02 Temmuz 2020.

Tetik, S. (2021). Covid-19 Pandemi sürecinin spor bilimleri ögrencilerinde fiziksel aktivite ve yaşam kalitesine etkisi. Yüksek Lisans Tezi, Çanakkale 18 Mart Üniversitesi, Lisansüstü Eğitim Enstitüsü, Beden Eğitimi ve Spor Anabilim Dalı, Çanakkale.

Vandongen, R., Jenner, D.A., Thompson, C., Taggart, A.C., Spickett, E.E., Burke, V. \& Dunbar, D. L. (1995). A controlled evaluation of a fitness and nutrition intervention program on cardiovascular health in 10-yearold to 12-year-old children. Preventive Medicine, 24(1), 9-22.

Yan, Y. (2007). 10-13 yaş çocuklarda sosyo-ekonomik yapının fiziksel aktivite ve fiziksel uygunluk düzeyine etkisi. Yüksek Lisans Tezi, Marmara Üniversitesi, Sağlık Bilimleri Enstitüsü, İstanbul.

Yanci, J., Cámara, J., Vizcay, J. J. \& Young, W. B. (2016). Examining age and gender effects in physical performance in young athletes aged 12-16 years. International Journal of Sports Science \& Coaching, $11(4), 538-544$.

Yıkılmaz, A. (2014). 8-12 yaş grubu ilkokul ve ortaokul ögrencilerinin performansla ilgili fiziksel uygunluklarının değerlendirilmesi. Yüksek Lisans Tezi, Gaziantep Üniversitesi, Sağlık Bilimleri Enstitüsü, Gaziantep.

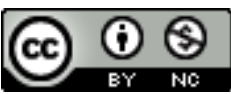

Bu eser Creative Commons Atıf-Gayri Ticari 4.0 Uluslararası Lisansı ile lisanslanmıştır. 